\title{
Mesoscale features of phytoplankton and planktonic bacteria in a coastal area as induced by external water masses
}

\author{
Raffaella Casotti ${ }^{1, *}$, Christophe Brunet ${ }^{1,2}$, Bianca Aronne ${ }^{3}$, Maurizio Ribera d'Alcala ${ }^{1}$ \\ 'Stazione Zoologica 'A. Dohrn', Villa Comunale, 80121 Naples, Italy \\ ${ }^{2}$ Université du Littoral, LISE, UPRES-A 8013, 62930 Wimereux, France \\ ${ }^{3}$ Istituto Universitario Navale, viale Acton, 80100 Naples, Italy
}

\begin{abstract}
The effects of different water masses and their physical structures on phytoplankton and bacteria were investigated in a coastal area of the Mediterranean Sea, the Gulf of Naples (Italy) on 9 and 10 November 1995. A small eddy $(8 \mathrm{~km}$ in diameter), generated from offshore waters, occupied the inner part of the Gulf at surface, while the Modified Atlantic Water (MAW) intruded between 60 and $80 \mathrm{~m}$ depth. Phytoplankton communities as identified by HPLC pigment analysis (total) and flow cytometry (ultraphytoplankton) showed peculiarities in the different subsystems. Cryptophytes dominated by pigment biomass were everywhere, while diatoms were more abundant at the coast and nanoflagellates at of fshore stations. In the MAW, a peculiar phytoplankton community, different to that in the other water masses, occurred, and 2 populations of prochlorophytes were distinguished based on scatter and red fluorescence observations. Total bacterial numbers were significantly correlated to chlorophyll a (chl a) concentrations. Different populations of heterotrophic bacteria were identified based on apparent DNA content. Percentages of 2 such populations were significantly correlated to total chl a. Therefore, phytoplankton appears to regulate not only bacterial quantity but also composition. Although our study area was characterized by a marked oligotrophy, heterotrophic bacterial biomass never exceeded autotrophic biomass, as derived using constant conversion factors of bacteria and chl a to $\mathrm{C}$. Therefore, no inverted pyramid was observed and bacterial biomass was still controlled by phytoplankton biomass. Mesoscale variability is of great relevance for energy and matter budgets of coastal areas and its study is therefore fundamental. For example, eddies can be very important in coastal areas, influencing distribution of nutrients and organisms. Our approach, coupling HPLC and flow cytometry, represents a valuable tool for obtaining information on both phytoplankton composition and ecophysiology on a large number of samples, necessary for a valid representation of the space scales involved.
\end{abstract}

KEY WORDS: HPLC - flow cytometry - Mediterranean Sea - Eddy - MAW

\section{INTRODUCTION}

Coastal areas are characterized by high hydrological variability which strongly influences light availability and the supply of nutrients. This gives rise to a high variability in time and space of algal biomass and productivity, mainly in regions of physical discontinuities and fronts. Few studies have addressed the effects of coastal variability on microbial activity and biogeo-

•E-mail: raffa@alpha.szn.it chemical cycles (exceptions include Yoder et al. 1993, Brunet et al. 1996), probably due to the difficulty of adequately sampling or of choosing the right indicators of the processes involved.

Eddies are among the manifestations of mesoscale instability; they strongly influence nutrient distribution and, therefore, may enhance or depress primary production (e.g. Falkowski et al. 1991). While much is known about oceanic gyres and eddies, very little literature is available on coastal eddies (e.g. Pingree et al. 1985). Their role in coastal areas can be very important 
for redistribution of terrestrial matter, dilution of pollutants, retention and/or recruitment of zooplankton (Murdoch 1989) and the transport and entrapment of larval or adult fish (Lobel \& Robinson 1986).

In the present study we describe and map mesoscale structures and their effects on phytoplankton biology in order to better understand the coupling between physical and biological processes. This coupling regulates the energy and matter tluxes of an area, influencing adaptation of phytoplankton to the environment at both the community and single-cell level, and the structure of inshore marine communities.

We used a combination of HPLC pigment analysis and flow cytometry to investigate phytoplankton variability at the spatial scale of a few miles ('mesoscale'). This methodological approach is rarely used in coastal studies, except to study specific populations of picoplankton (Veldhuis \& Kraay 1990, Bautista \& JiménezGòmez 1996). By using both techniques simultaneously one can thoroughly analyze phytoplankton communities and obtain information not only on abundances, but also on their acclimation and physiological states. Marker pigments can be used to estimate the contribution of different algal groups to total phytoplankton biomass (Peeken 1997), and the pigment ratio $F p$ (ratio of marker pigments of diatoms and dinoflagellates to the sum of diagnostic pigments of all taxa) is an estimator of the proportion of new producers' biomass (Claustre 1.994). In addition, photoprotective pigments, which are produced when cells are exposed to excessive irradiances, give information on the ecological past of the cells (Brunet et al. 1993, Claustre et al. 1994). Flow cytometry is used to discriminate and count several small-size algal groups (35 $\mathrm{mm}$ is the maximum size analyzed by our instrument) and bacteria, based on scatter and fluorescence. In addition, this technique can detect very weak fluorescence signals as from prochlorophyte cyanobacteria (e.g. Li et al. 1992).

High heterogeneity and hydrodynamical complexity make the Gulf of Naples an ideal site for studying phytoplankton variability at the mesoscale. The variability is due to a complex bottom topography that influences hydrography and randomly distributed land runoffs whose dilution patterns strongly influence biology. Coastal eutrophic waters border oligotrophic Tyrrhenian waters all year around (Zingone et al. 1995). Several other water masses may also be present in the Gulf, depending on the season (Povero et al. 1990). The Tyrrhenian Intermediate Water (TIW) occupies the surface layer down to $200 \mathrm{~m}$, representing $75 \%$ of the total volume of the Gulf. The Atlantic waters intrude into the surface layer of the Mediterranean Sea both in summer and in winter (Fedorov 1972), forming a less dense surface layer, referred to as
Tyrrhenian Atlantic Water (TAW) (Povero et al. 1990), or Modified Atlantic Water (MAW). At the same time, the upper wind-mixed portion of the TAW diverges and it becomes saltier and warmer due to insolation and evaporation. Below the TIW is the Levantine Intermediate Water (LIW), which flows from the Sicily Strait, and at the bottom is the Tyrrhenian Deep Water (TDW). Wind and topographic discontinuities generate a complex and variable combination of these water masses (Moretti et al. 1976/77). The circulation of the surface waters and its seasonal variability is due mainly to the properties of the wind field over the water area, and is at times complicated by small-scale eddies of various dimensions (De Maio et al. 1978/79).

Previous data on ultraphytoplankton and heterotrophic bacteria in the Gulf of Naples are quite rare (Modigh et al. 1996). The populations of larger size classes of phytoplankton develop blooms in late spring-early summer with monthly mean primary production values $>1 \mathrm{~g} \mathrm{C} \mathrm{m}^{-2}$ A second autumn bloom occurs later, at times when meteorological and light conditions are favourable (Scotto di Carlo et al. 1985). Previous studies (Zingone et al. 1995) showed a high diversity in phytoplankton species, and high variability in abundances and composition inside the gulf.

The aim of this paper is to investigate the biological characteristics of water masses and mesoscale physical structures present in the Gulf of Naples in autumn. The general aim is to find indicators of physical processes and hydrodynamical regimes at the mesoscale that can be used for modelling coastal areas.

\section{MATERIALS AND METHODS}

Sample collection. Samples were collected from the inner part of the Gulf of Naples on 9 and 10 November 1995 along 3 coast-to-offshore transects (Fig. 1). Hydrographic measurements of temperature and salinity were collected with a CTD profiler (SBE 911+, Seabird Electronics, USA) equipped with a 10 I Niskin bottle rosette sampler for seawater collection. Upwelling and downwelling irradiance (PAR) were measured using a PrimProd probe $(2 \pi$, EcoMonitor, Russia). Discrete seawater samples were collected at $2,10,20,40$ and $70 \mathrm{~m}$. Samples for the determination of nitrate, nitrite, silicic acid and phosphate $(20 \mathrm{ml})$ were immediately frozen. Samples for pigment analysis (2 l) were filtered through $47 \mathrm{~mm}$ Whatman GF/F filters, wrapped in aluminum foil and stored at $-20^{\circ} \mathrm{C}$, and analyzed within 2 wk of sampling. Duplicate samples for flow cytometry $(1 \mathrm{ml})$ were placed in $1.5 \mathrm{ml}$ cryovials, fixed $15 \mathrm{~min}$ with $0.5 \%$ glutaraldehyde (final concentration), flashfrozen in liquid nitrogen (Vaulot et al. 1989) and stored at $-80^{\circ} \mathrm{C}$ until they were analyzed. 


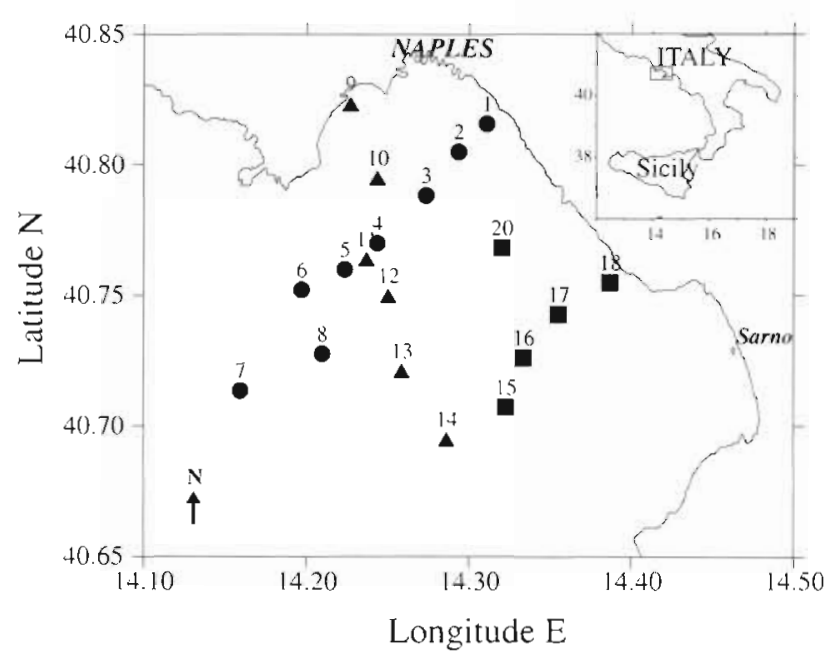

Fig. 1. Map of the Gulf of Naples with sampling stations. Transect 1 . Stns 1 to $8(\bullet)$. Transect 2: Stns 9 to $14(\mathbf{A})$. Transect 3 : Stns 14 to 18

Pigment analysis. Frozen filters were extracted in $4 \mathrm{ml} \mathrm{100 \%} \mathrm{methanol} \mathrm{by} \mathrm{mechanical} \mathrm{grinding} \mathrm{and} \mathrm{the}$ extracts filtered through Whatman GF/F filters. The HPLC protocol is detailed in Brunet et al. (1993). Pigments were identified and quantified by comparison with retention times and concentrations of standard pigments by Sigma Chemical Company (chlorophylls a [chl $a$ ], $b$ and $\beta$-carotene) or by the Water Quality Institute-International Agency for ${ }^{14} \mathrm{C}$ Determination (Denmark).
Twenty-two acetone-extractable phytoplankton pigments, including biomarker pigments and pigment degradation products, were resolved. Although our method did not allow separation of chl a and divinyl chl $a$, in our chromatograms a shoulder in the chl a peak was noted and attributed to divinyl chl $a$. This interpretation was confirmed by flow cytometric detection of prochlorophytes (Chisholm et al. 1988). The composition of the phytoplankton communities, expressed in percentage biomass of total chl $a$, was estimated from the concentrations of marker pigments in conjunction with pigment/chl a ratios to characterise the different algal groups (Peeken 1997). Conversion factors listed in Table 1 were derived from culture experiments on selected species grown at different light regimes and intensities (C. Brunet \& R. Casotti unpubl. data) or from the literature. The conversion factors were then multiplied by the concentrations of specific marker pigment to calculate the group-specific chl a values.

The relative contribution of cyanobacteria and prochlorophytes to chl a was estimated by using the average of zeaxanthin:chlorophyll values found in the literature (Kana \& Gilbert 1987 for cyanobacteria, and Partensky et al. 1993 for prochlorophytes). These values were multiplied by the respective cell numbers of cyanobacteria and prochlorophytes as calculated from flow-cytometric analyses in order to estimate their contribution to total chlorophyll biomass. Similarly, we discriminated the contribution of prochlorophytes from that of chlorophytes, estimated from chl b/chl a ratio (C. Brunet \& R. Casotti unpubl. data). In this way we

Table 1. Pigment markers, conversion factors and contribution of different phytoplankton groups to total chlorophyll and $F \mathrm{p}$ ratio. Conversion factors were used to determine the different amounts of the algal classes to chlorophyll a. Fp is calculated as from Claustre (1994), modified according to Eq. 2 (in the text). 19'BF =19'butanoyloxyfucoxanthin, 19' HF = 19' hexanoyloxyfucoxanthin

\begin{tabular}{|c|c|c|c|c|c|c|c|c|c|}
\hline & Diatoms & $\begin{array}{l}\text { Dino- } \\
\text { flagellates }\end{array}$ & $\begin{array}{l}\text { Prymnesio- } \\
\text { phytes }\end{array}$ & $\begin{array}{l}\text { Crypto- } \\
\text { phytes }\end{array}$ & $\begin{array}{l}\text { Chloro- } \\
\text { phytes }\end{array}$ & $\begin{array}{l}\text { Pelago- } \\
\text { phytes }\end{array}$ & $\begin{array}{l}\text { Cyano- } \\
\text { bacteria }\end{array}$ & $\begin{array}{l}\text { Prochloro- } \\
\text { phytes }\end{array}$ & $F_{\mathrm{p}}$ \\
\hline $\begin{array}{l}\text { Pigment } \\
\text { marker }\end{array}$ & Fucoxanthin & Peridinin & $19^{\prime} \mathrm{H} . \mathrm{F}$ & Alloxanthin & Chlorophyll $b$ & $19^{\prime} \mathrm{BF}$ & Zeaxanthin & Zeaxanthin & \\
\hline $\begin{array}{l}\text { Conversion } \\
\text { factors }\end{array}$ & $(1.25)^{d}$ & $(1.00)^{\circ}$ & $(0.80)^{\mathrm{a}}$ & $(1.6)^{\prime \prime}$ & $(1.5)^{d}$ & $(1.20)^{\mathrm{b}}$ & $(2.0)^{\varsigma}$ & $(1.70)^{\mathrm{d}}$ & \\
\hline $\begin{array}{l}\text { Coast } \\
(n=29)\end{array}$ & 26.0 & 1.7 & 16.1 & 41.6 & 3 & 6.9 & 3.4 & 0.5 & 0.277 \\
\hline $\begin{array}{l}\text { Offshore } \\
{[n=20\}}\end{array}$ & 7.9 & 0.7 & 19.8 & 52.8 & 7.5 & 9.8 & 0.9 & 0.3 & 0.086 \\
\hline $\begin{array}{l}\text { Eddy } \\
(n=12)\end{array}$ & 82 & 0.6 & 20.0 & 53.4 & 6.3 & 10.0 & 1.1 & 0.4 & 0.088 \\
\hline $\begin{array}{l}\text { Transition layer } \\
(n=12)\end{array}$ & 32.0 & 1.5 & 28.6 & 3.43 & 11.4 & 15.5 & 4.5 & 2.7 & 0.337 \\
\hline $\begin{array}{l}\text { MAW } \\
(n=14)\end{array}$ & 14.6 & 0.6 & 22.9 & 1.5 & 27.8 & 24.6 & 0.7 & 7.1 & 0.152 \\
\hline
\end{tabular}


could relate bulk measurements of pigments (by HPLC) to intrinsic parameters on a single-cell basis (by flow cytometry)

Fp ratio. The Fp ratio (Claustre 1994) is the ratio between diatom and dinoflagellate pigment markers, considered as major users of nitrates to fuel photosynthesis, and the sum of all pigments. It has been proposed as an indicator of trophic status and an estimator of the $f$-ratio (Eppley \& Peterson 1979), the ratio of new production versus total production.

We calculated $F$ p from our data using the following equation

$F \mathrm{p}=\frac{\text { fucoxanthin }+ \text { peridinin }+ \text { zeaxanthin }}{\text { fucoxanthin }+ \text { peridinin }+ \text { zeaxanthin }+19^{\prime} \mathrm{BF}+19 \mathrm{HF}+\text { chlorophyll } b+\text { alloxanthin }}$

Our formulation of the $F p$ ratio was slightly modified from the original by the introduction of the zeaxanthin contribution from cyanobacteria in the above term, in addition to fucoxanthin (diatoms) and peridinin (dinoflagellates). This modification was based on the consideration that zeaxanthin (from cyanobacteria) was directly correlated with fucoxanthin and peridinin concentrations $(\mathrm{p}<0.05)$. In addition, these 3 pigments were also significantly correlated with nitrate $(p<$ $0.05)$, validating the interpretation of $F \mathrm{p}$ in terms of mutrient fluxes. It therefore appeared that diatoms, dinoflagellates and cyanobacteria were using nutrients in a similar way. In any case, contribution from cyanobacteria was quite low, and became insignificant for calculation of the ratio.

Flow cytometry. Phytoplankton cell counts and light scatter versus fluorescence signatures of the various groups of particles were obtained using a FACScalibur flow cytometer (Becton Dickinson, USA), equipped with standard laser and filter set (Li 1995). Fluorescence and light scatter data were collected as log signals and recorded over a 4 decade range with 1024 channel resolution. Flow Set beads $(3.6 \mu \mathrm{m}$, Coulter, USA) were added to the samples and used as internal standards to check instrument alignment and performance. For the analysis of unstained plankton samples, the delivery rate was $44 \mu \mathrm{lmin} \mathrm{m}^{-1}$ and samples were run for $300 \mathrm{~s}$. Flow rate was calibrated by weighing a tube containg $2 \mathrm{mI}$ of filtered seawater before and after a $30 \mathrm{~min}$ run. By dividing the difference in weight by the run time, the flow rate in $\mu \mathrm{lmin}{ }^{-1}$ was obtained. Cyanobacteria, prochlorophytes and eukaryotes were identified based on multiple bivariate scatterplots as described by Olson et al. (1993).

For the analysis of heterotrophic bacterial numbers, a $1 \mathrm{ml}$ sample was stained with the fluorescent DNA stain TOTO-1 (Molecular Probes), according to the protocol of $\mathrm{Li}$ et al. (1995). Green fluorescence from TOTO-1 was collected in the FL1 channel after passing through a $530 \pm 30 \mathrm{~nm}$ filter. Compensation was not used and no absolute standards were used. A sample of stained sheath fluid was run before each series of stained samples to equilibrate the sample line.

Since the DNA content of bacteria overlapped with that of prochlorophytes, the number of the latter was subtracted from the total number of bacteria. Considering the low numbers of prochlorophytes with respect to heterotrophic bacteria, the correction was insignificant. Bacterial counts most probably included the nonnucleoid containing cells noted by Zweifel \& Hagström (1995) and both Eubacteria and Archaea.

Even though Synechococcus and Prochlorococcus are bacteria, we include them as 'ultraphytoplankton', together with eukaryotes, based on their trophic characteristics. Heterotrophic non-pigmented bacteria will be referred to as 'bacteria', while ultraphytoplankton and bacteria together will be referred to as 'ultraplankton' (sensu Li 1997). This classification reflects the fact that we did not measure actual size, since we used light scatter as a proxy of size.

Counts of bacteria and ultraphytoplankton were converted to carbon $\left(\mu \mathrm{g} \mathrm{Cl}^{-1}\right)$ using the factor $20 \mathrm{fg} \mathrm{C}$ per bacterium, $250 \mathrm{fg} \mathrm{C}$ per cyanobacterium, $53 \mathrm{fg} \mathrm{C}$ per prochlorophyte cell, and $2100 \mathrm{fg} C$ per eukaryote cell, as outlined in Campbell et al. (1994). Total carbon biomass for all phytoplankton cells was calculated from chl a concentrations using a $\mathrm{C}$ to chlorophyll ratio of 50 (Fuhrman et al. 1989).

Statistical analyses. Comparisons of means throughout the paper were realized by means of Student's $t$-test using Systat software (SPSS Inc., USA). Principal component analysis (PCA) was used to extract main patterns from all data collected. The analysis was based on correlation matrices involving the standardization of each variable to zero mean and unit variance. The first 2 axes accounted for $96 \%$ of variance.

\section{RESULTS}

\section{Hydrography and nutrient data}

A homogeneous mixed layer surface of approximately $20 \mathrm{~m}$ depth was present throughout the studied area. Coastal conditions graded gradually into offshore subsystems and were identified mainly on the basis of salinity and temperature values, which increased in a coast to offshore direction (Fig, 2a,b). CTD casts over $100 \mathrm{~m}$ depth (not shown) showed that a salinity minimum layer extended between 60 and $80 \mathrm{~m}$ throughout the area sampled. Salinity minima between 36.7 and 38.4 psu are generally considered as characteristic of the MAW (Krivosheya 1983). Fig. 3b represents the general structure of the water column, with a mixed 

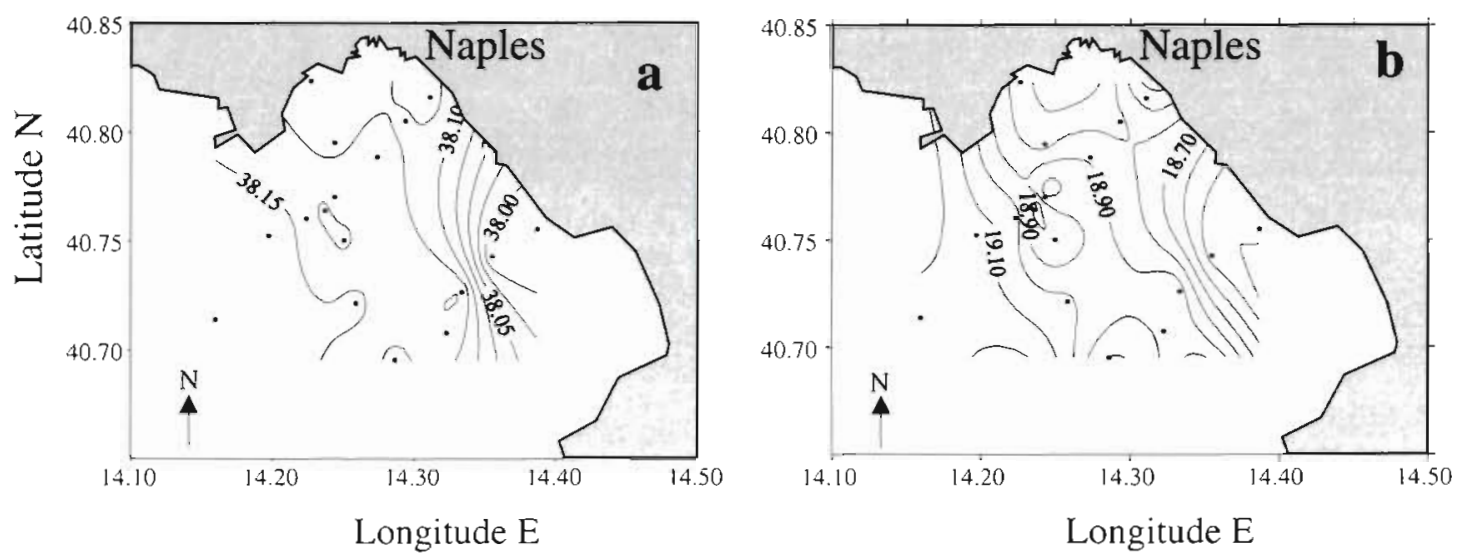

Fig. 2. Surface $(2 \mathrm{~m})$ values of (a) salinity (PSU) and (b) temperature $\left({ }^{\circ} \mathrm{C}\right.$ ) during the sampling

surface layer, separated from a lower salinity deep water, the MAW. A sharp halocline (and pycnocline) separated the 2 water masses, representing an horizontal front, which we will call the 'transitional layer'. Also, the more saline water visible at Stns 12,13 and 14 was representative of an eddy (Fig. $3 \mathrm{~b}$ ). This eddy was also warmer than surrounding waters (Fig. 3a), as visible also from Advanced Very High Resolution Radiometer (AVHRR) satellite data from the Gulf of Naples on November 9 (first day of sampling - not shown).

Nitrogen concentrations (nitrate plus nitrite) ranged from 0.20 to $2.39 \mu \mathrm{M}$ in the upper $20 \mathrm{~m}$, while phosphate concentrations ranged from 0.01 to $0.21 \mu \mathrm{M}$
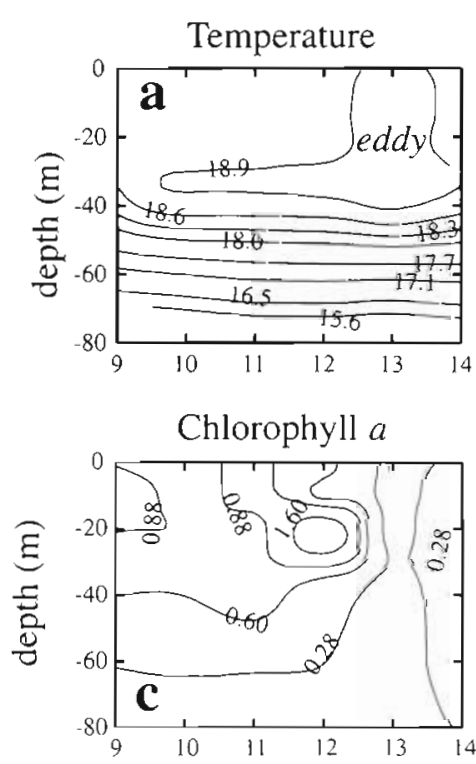

NNW station number SSE

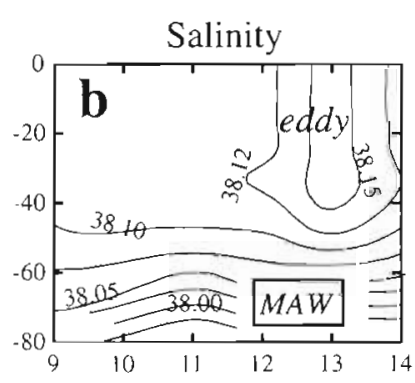

Diatoxanthin/chlorophyll $a$

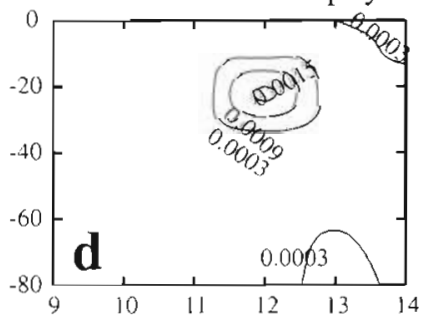

NNW station number SSE
Fig. 3. Vertical profiles of (a) temperature $\left({ }^{\circ} \mathrm{C}\right.$ ), (b) salinity (PSU) (c) chl a ( $\left.\mathrm{g} \mathrm{I} \mathrm{l}^{-1}\right)$ and (d) diatoxanthin to chl a ratio along Transect 2 (NNW to SSE direction: Stns 9 to 14 ) (data not shown). In general, nutrient concentrations were homogeneous throughout the water column, with only a slight increase with depth.

\section{Phytoplankton pigments}

Average concentrations of chl $a$ in the first $20 \mathrm{~m}$ ranged between 0.26 and $1.16 \mu \mathrm{g} \mathrm{l}^{-1}$, and decreased from the coast to offshore, with the lowest concentrations found inside the eddy. Average chl a values for coastal and offshore stations were not significantly different $(p>0.05)$. At Stn 12, where a front separated the eddy from surrounding waters, accumulation of biomass occurred (Fig. 3c), with the highest concentrations of chl a for the whole area $\left(1.85 \mathrm{\mu g} \mathrm{l}^{-1}\right)$. The same accumulated biomass was rich in diatoxanthin, a photoprotectant pigment of brown algae (Fig. 3d).

Below $20 \mathrm{~m}$, where stratification occurred, chl a concentrations were equal to or less than in the above layer, ranging from 0.11 to $0.87 \mu \mathrm{g} \mathrm{I}^{-1}$. Within the MAW concentrations dropped, ranging from 0.14 to $0.46 \mu \mathrm{g} \mathrm{I}^{-1}$, probably because of changes in phytoplankton population structure and low light intensities.

Cryptophytes were the most abundant algae in the surface layer ( 0 to $20 \mathrm{~m}$ ) at all stations, with proportions varying from 41.6 to $53.4 \%$ of the total phytoplankton biomass (Table 1). At coastal stations, diatoms were the second most abundant group (26\%), followed by prymnesiophytes (16.1\%). Phytoplankton community composition was similar offshore and in the eddy. Prymnesiophytes were the second major contributors to biomass (about 20\% in both) after cryptophytes, followed by pelagophytes (about 10\%). The MAW exhibited its own distinct community, composed 

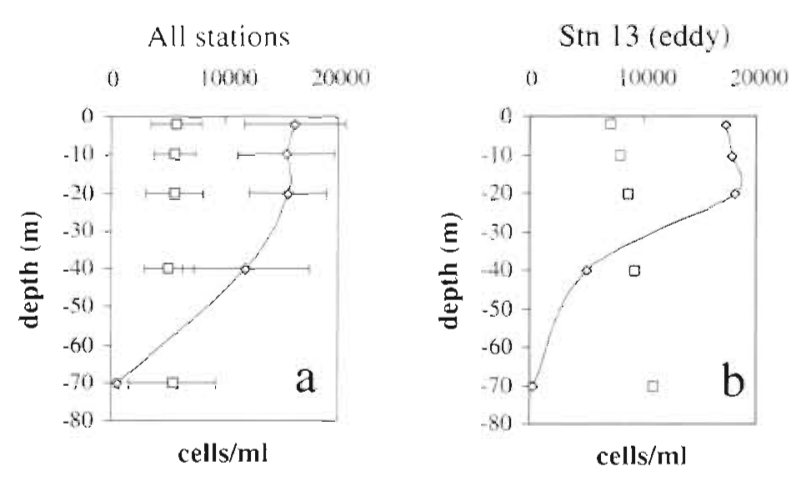

All stations

() $1000 \quad 2000 \quad 3000 \quad+0000$

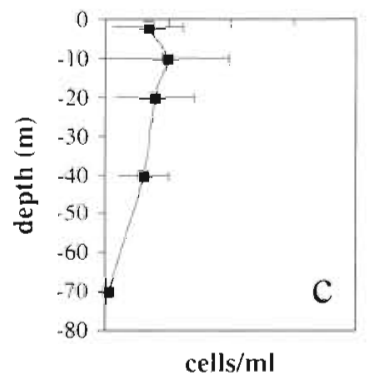

(0.152), the transition layer had a value very close to the coastal value $(0.337)$ due to its high proportion of diatoms.

\section{Ultraplankton}

Cyanobacteria (Synechococcus sp.) were 1 order of magnitude more abundant than prochlorophytes and were generally resiricted to the upper $20 \mathrm{~m}$ at the coast and to the upper $40 \mathrm{~m}$ offshore. Mean abundances were $1.6 \times 10^{4}$ cells $\mathrm{ml}^{-1}$ at the surface (SD $\pm 4.4 \times 10^{3}$ ). (Fig. 4a). Very few Synechococcus sp. were found in the MAW, where average abundance was $5.0 \times 10^{2}$ cells $\mathrm{ml}^{-1}\left(\mathrm{SD} \pm 1.0 \times 10^{2}\right)$. Prochlorophytes averaged $5.5 \times 10^{3}$ cells $\mathrm{ml}^{-1}$ (Fig. 4a) and were more abundant offshore and in the eddy (Fig. 4b).

In contrast with Vaulot \& Partensky (1989), no correlation was found between prochlorophyte and cyanobacterial abundances or cell parameters, such as light scatter or fluorescence $(p>0.05)$, perhaps due to a different vertical distribution of these 2 cell types. Cyanobacteria were mostly present above the thermocline while prochlorophytes were preseni throughout the water column, but with no subsurface peak. We must conclude that the 2 cell types did not respond to the same environmental constraint in the studied area in the winter. This distribution more closely resembled distributions in truely oligotrophic regions, such as the Sargasso Sea (Chisholm et al. 1988, Li \& Wood 1988) or the Pacific Ocean (Campbell et al. 1994) than geographically closer areas (Vaulot et al. 1990, Bautista \& Jimenez-Gomez 1996).

Prochlorophytes in the MAW always showed a bimodal distribution of size and red-fluorescence (Fig. 5). Such bimodality was attributed to the coexistence of physiologically different ecotypes of prochlorophytes where conditions are favourable to both (Moore et al. 1998).

The mean fluorescence per cell, measured by flow cytometry, which is an index of chl a concentration, increased with depth for all ultraphytoplanktonic components of the community. Prochlorophyte chlorophyll fluorescence was always low in the 0 to $20 \mathrm{~m}$ layer and higher in the deeper layer (Fig. 6a). The average increase between the low fluorescence and the high fluorescence layers ranged from 6 to 10 times. Cellular chlorophyll fluorescence for cyanobacteria also increased with depth, but less than for prochlorophytes (maximum 3 times, Fig. 6b). Because cyanobacterial cell numbers were often very low below $40 \mathrm{~m}$, statistical anal sis to compare the average increase was not possible.

Cyanobacterial orange fluorescence from phycoerythrin also increased with depth, although the increase
As expected, Fp was highest at coastal stations (0.277), and lowest offshore and in the eddy, which showed similar values $(0.086$ and 0.088 , respectively) (Table 1). While the MAW exhibits intermediate values 

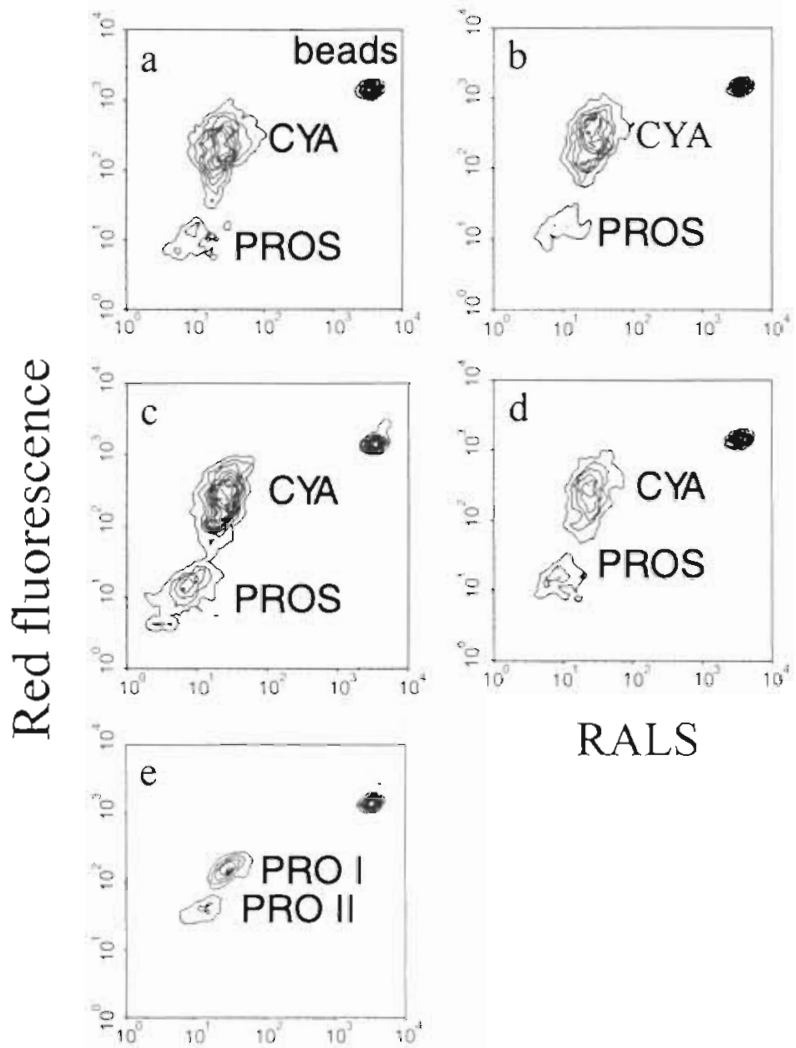

RALS

Fig. 5. Flow cytometric signatures of prochlorophytes and cyanobacteria down the water column at $\operatorname{Stn} 5$. (a), (b), (c), (d) and (e) are from $2,10,20,40$ and $70 \mathrm{~m}$ depths, respectively. RALS (right angle light scatter) is a proxy of size. CYA = cyanobacteria, $\operatorname{PRO}(S)=$ prochlorophyte $(s)$. Note the second population of prochlorophytes at $70 \mathrm{~m}$ (PRO II). Beads are $3.6 \mu \mathrm{m}$ polystyrene beads, as indicated in the 'Materials and methods' section

was less pronounced than for the chlorophyll fluorescence (not shown).

Average abundance of eukaryotes was $7.6 \times 10^{2}$ cells $\mathrm{ml}^{-1}\left(\mathrm{SD} \pm 1.7 \times 10^{2}\right)$ in the first $40 \mathrm{~m}$. These algae were restricted to surface and coastal waters (Fig. 4c,d). No subpopulations could be distinguished, based on scatter or fluorescence, and no PE-containing cells were ever detected, suggesting that the alloxanthin-containing algae classified as cryptophytes were represented by cells larger than $6 \mu \mathrm{m}$, which was the limit of detection of our flow cytometer settings. This was also confirmed by microscopic analysis of several samples ( $M$. Montresor pers. comm.).

Maximum bacterial abundances occurred in the surface mixed layer (average was $1.7 \times 10^{5}$ cells $\mathrm{ml}^{-1} \mathrm{SD} \pm$ $5.7 \times 10^{4}$ ) and were highest in the eastern coastal part of the Gulf ( $\operatorname{Stn} 18 ; 1.9 \times 10^{6}$ cells $\mathrm{ml}^{-1}$ ), where the influenre of the Sarno River flow is stronger. Lowest cell concentrations $\left(2 \times 10^{5}\right.$ cells $\left.\mathrm{ml}^{-1}\right)$ were found in the eddy $(\operatorname{Stn} 13)$.

Vertical profiles of bacteria were essentially uniform and only slightly decreased with depth (Fig 7), except in the front (Stn 12). Here cell numbers were lowest at the surface and then increased by a factor of 2.5 between 10 and $40 \mathrm{~m}$ (Fig. 7d), following the phytoplankton distribution (Fig 3c). Cell numbers were always relatively low (between 1 and $3 \times 10^{5}$ cells $\mathrm{ml}^{-1}$ ) at $70 \mathrm{~m}$ inside the MAW.

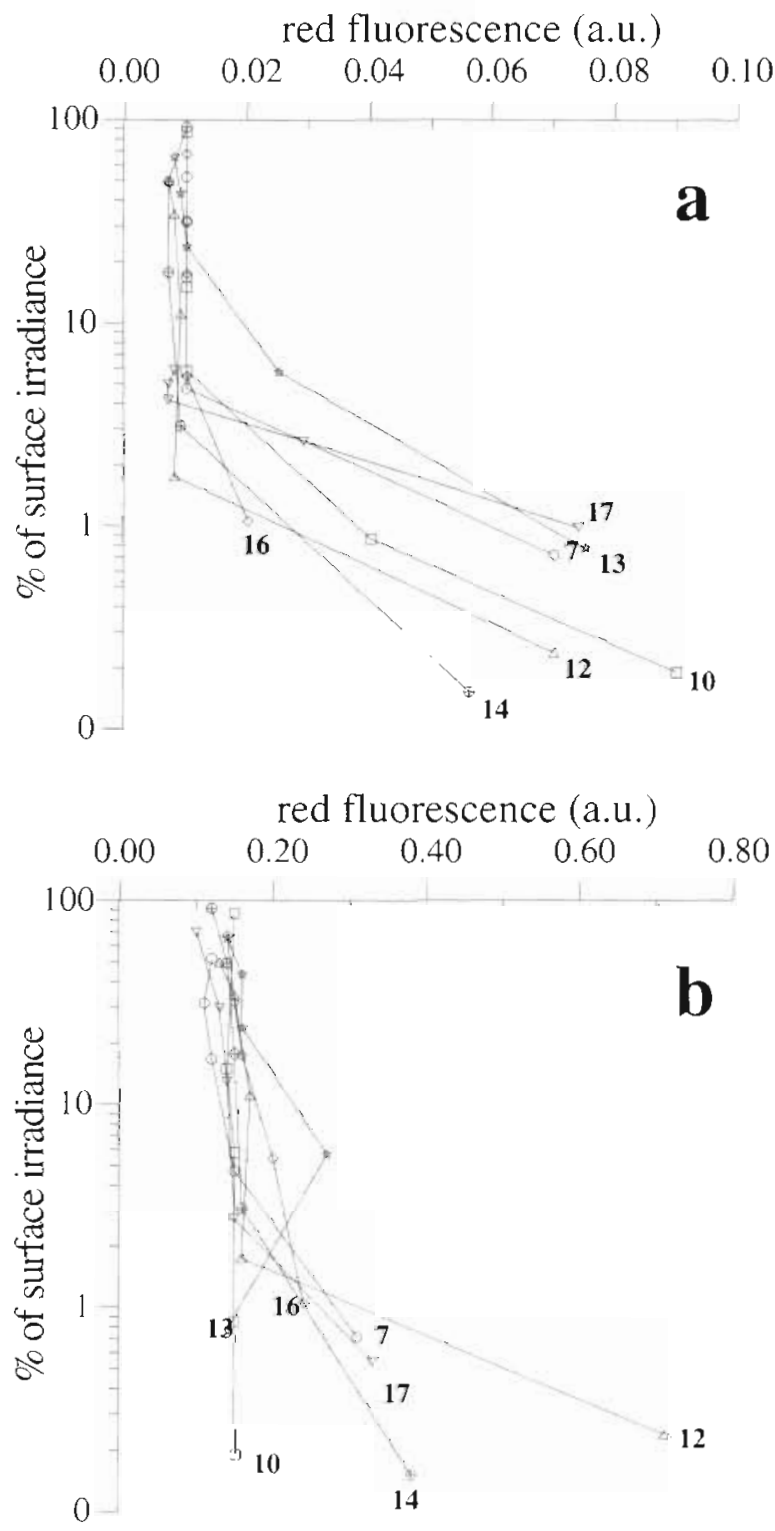

Fig. 6. Vertical profiles of red fluorescence of (a) prochlorophytes and (b) cyanobacteria as a function of percent of surface irradiance at selected stations, representative of the different water masses encountered. Numbers indicate stations. Values are arbitrary units (a.u.) relative to the beads 

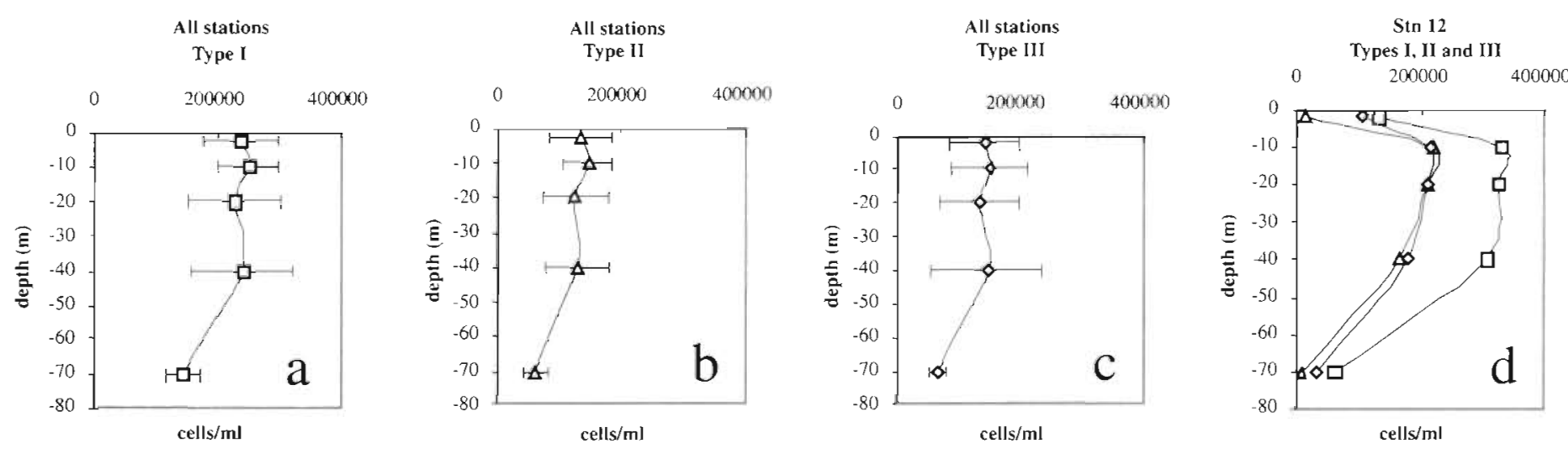

Fig. 7. Mean values for heterotrophic bacteria in the Gulf of Naples. Mean concentrations (cells ml ${ }^{-1}$ ) and standard deviations of (a) Type I, (b) Type II and (c) Type III bacteria, as identified based on apparent DNA content. (d) Vertical distribution of Type I (D), Type II ( $\Delta$ ) and Type III ( $\diamond)$ at Stn 12 (front)

Based on apparent DNA content, 3 populations were identified at all stations. We followed Li et al. (1995) in naming them Type I, II or III. The lowest DNA population (Type I) was dominant in all samples examined (Fig. $7 \mathbf{a}, \mathbf{b}, \mathbf{c}$ ), except at the surface in coastal stations of the eastern part of the Gulf, where Group III accounted for 60 to $66 \%$ of total counts. This was probably an effect of inputs from the Sarno River. At the surface at Stn 13, where the lowest chl a and bacterial concentrations were registered, Type I bacteria accounted for $69 \%$ of total bacteria, while Type II bacteria were almost absent ( $2 \%)$

Total bacterial concentrations were significantly correlated to chl a concentrations according to Eq. 3):

$$
\log \left(\text { bacteria } \mathrm{ml}^{-1}\right)=5.89+0.66 \log (\operatorname{chl} a)
$$

with $\mathrm{r}=0.74, \mathrm{n}=65, \mathrm{p}<0.01_{\mathrm{i}} \mathrm{chl} \mathrm{a}$ is expressed in $\mu \mathrm{gl}^{-1}$ (Fig. 8a). The $95 \%$ confidence limits for an individual prediction lay between 5.81 and 5.95 for b and 0.50 and 0.81 for a (considering the linear correlation as $y=$ $a x+b)$.

Type I bacteria were significantly correlated to chlorophyll concentrations according to Eq (4):

$$
\% \text { of Type } I=39.75-20.11 \log (\mathrm{chl} a)
$$

with $r=-0.54, n=65, p<0.001$ (Fig. 8b).

Type III bacteria, instead, were correlated to chl a with an opposite sign. Regression gave:

$$
\% \text { of Type III }=33.72+16.21 \log (\operatorname{chI} a)
$$

with $r=0.54, n=56, p<0.001$ (Fig. 8c).

Bacterial carbon averaged $68 \%(\mathrm{SD} \pm 15 \%)$, while ultraphytoplankton was $32 \%(S D \pm 15 \%)$ of the carbon in the microbial community (bacteria plus ultraphytoplankton). Highest mean carbon biomass occurred at coastal stations above the MAW (mean $19.14 \mu \mathrm{g} \mathrm{l}^{-1}$, SD $\left.\pm 7.46 \mu \mathrm{g} \mathrm{l}^{-1}\right)$, and the lowest in the MAW $\left(5.70 \mu \mathrm{g} \mathrm{l}^{-1}\right.$ $\mathrm{SD} \pm 1.43 \mu \mathrm{g} \mathrm{l}^{-1}$ )

Total carbon (phytoplankton plus bacteria, calculated as described at the end of the 'Materials and methods' section) ranged from 7.11 to $108 \mu \mathrm{g} \mathrm{I}^{-1}$. Mean contribution from phytoplankton was $70 \%(\mathrm{SD} \pm 8 \%$ ) and was never lower than $50 \%$. Contribution from bacteria ranged from 15 to $50 \%$, averaging $30 \%$ (SD \pm $8 \%$ ). From these data it appeared that the autotrophs dominated the heterotrophs throughout the area, even at the most oligotrophic stations (Stns 7 and 13), in contrast to the inverted biomass pyramid of Cho \& Azam (1990).

\section{DISCUSSION}

Previous investigations of the Gulf of Naples in autumn revealed the repeated occurrence of a phytoplankton bloom triggered by favourable climatic conditions (Zingone et al. 1995). Our sampling missed this bloom, which occurred later in 1995 and was also less intense than normal, as revealed from data collected weekly at a coastal station for more than 5 yr (F. Corato pers. comm.).

Our biological data more realistically reflected a winter situation, with low biomass and nutrient concentrations, as also indicated by the higher temperatures measured offshore. Even though the halocline present at depth could represent a residual of the summer stratification, it is most probably generated by the intrusion of the MAW into the Gulf

Typical coastal and offshore stations showed very different trophic status and phytoplankton communities, indicating that the area was not homogeneous and 

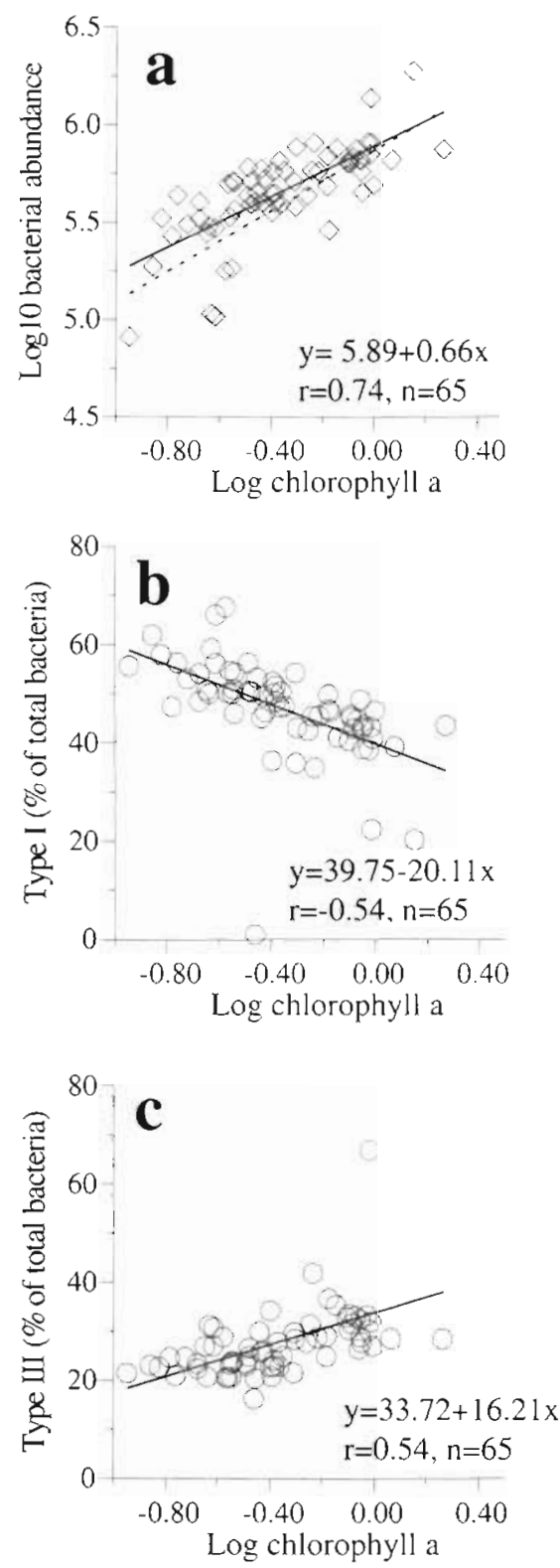

Fig. 8. Correlations with chl à concentrations $\left(\mu \mathrm{g} \mathrm{l^{-1 }}\right)$. (a) Total bacterial abundances in cells $\mathrm{ml}^{-1}$ (Eq. 2 in the text). (-..-) Equation of Bird \& Kalff (1984). (b) Percentage of bacteria belonging to the heterogeneous low apparent DNA Type I (Eq. 3 in the text). (c) Percentage of bacteria belonging to the heterogeneous higher apparent DNA Type III (Eq. 4 in the text)

that different 'ecological provinces' were present. The dominance of cryptophytes all over the sampled area could be an indicator of instability of the system. In fact, cryptophytes indicate a relatively unstructured community (Stewart \& Wetzel 1986), which profits from the instability that follows the autumn bloom and preceeds proper winter conditions. This interpretation is in agreement with ecosystem maturation and the role of regenerated nutrients (from bacteria and/or zooplankton grazing) on biological production of some algal groups (Andersen \& Nival 1989, Claustre et al. 1994).

In addition to cryptophytes, the phytoplankton communities had different compositions in the different hydrological subsystems, with more diatoms at the coast and more pelagophytes and chlorophytes offshore. As a consequence, $F$ p also decreased from the coast to offshore, indicating that biological and chemical characteristics of the water masses were strictly linked. Values of $F \mathrm{p}$ at the offshore sites were very close to those indicated by Claustre (1994) for the Mediterranean Sea, but our coastal system $(F \mathrm{p}=0.28)$ was very different from his eutrophic site $(0.76 \pm 0.22)$. Of course, the Gulf of Naples is a highly dynamic coastal area, in which standing stocks and fluxes are far from being in equilibrium, and so cannot be easily compared with well-defined oceanic conditions. In fact, our coastal values fell into the range of mesotrophic regimes of the Atlantic Ocean $(0.15 \pm 0.60)$ or the Mediterranean Sea $(0.35$ to 0.85$)$, where a large Fp-ratio variability has been observed.

Despite the low values of chlorophyll $\left(<1 \mu \mathrm{g} \mathrm{l}^{-1}\right)$ and nutrients which have been reported to enhance the relative contribution of picophytoplankton to total biomass (Modigh et al. 1996), cyanobacteria and prochlorophytes accounted for a low proportion of total chlorophyll biomass throughout the sampled area (contributing to a maximum of $7.8 \%$ of the total $\mathrm{chl} a$ ). This finding, and also the numerical dominance of cyanobacteria over prochlorophytes, is consistent with observations in another coastal station of the northwestern Mediterranean Sea (Stn B in the Villefranchesur-Mer Bay, France, Bustillos-Guzman et al. 1995), where peaks of cyanobacteria occurred after mixing, and prochlorophytes occurred only in a stratified, more stable water column. It is noteworthy that although small, the contribution of picophytoplankton to total biomass was significant, maintaining a stable level in the coastal pelagic system of the Gulf of Naples.

The significant relationship between bacterial numbers and chlorophyll concentrations is very similar to, and fell within the confidence limits for, a prediction equation by Bird \& Kalff (1984), who first related bacterial numbers to chlorophyll concentrations for a wide range of freshwater and marine systems (Fig. 8a; dashed line). Also, average concentrations of bacteria calculated using both equations were not significantly different $(p>0.05)$. This relation also held true for chlorophyll concentrations lower than $0.5 \mu \mathrm{g} \mathrm{l}^{-1}$ ( $\mathrm{r}=$ $0.73, n=39, p<0.001)$, even without the lowest value for chlorophyll $\left(0.11 \mathrm{\mu g} \mathrm{l}^{-1} ; \mathrm{r}=0.71, \mathrm{n}=38, \mathrm{p}<0.001\right)$. These results are different from those of Cho \& Azam (1990), who found a lower threshold for bacterial numbers of $3 \times 10^{5}$ cells $\mathrm{ml}^{-1}$ in several sites of the Pacific 
Ocean and concluded that below $0.5 \mu \mathrm{g} \mathrm{I}^{-1}$ of chl a the autotrophic biomass decrease is accompanied by a much lower decrease in bacterial abundance. This would mean that in oligotrophic areas the food web can be dominated by decomposer biomass, and that consumer biomass could exceed producer biomass. representing an 'inverted pyramid'. Although this phenomenon has been reported from other areas (e.g. Li et al. 1993), investigations in the Eastern Mediterranean Sea did not support these conclusions, as bacterial biomass represented only 25 to $77 \%$ of phytoplankton biomass (Robarts et al. 1996). In addition, the degree of heterotrophy has been overestimated in the past by using chlorophyll as an indicator of autotrophic biomass (Buck et al. 1996). In our case, although $60 \%$ of our chlorophyll data are lower than $0.5 \mathrm{\mu g} \mathrm{l}^{-1}$, (min $0.11 \mathrm{\mu g} \mathrm{l}^{-1}$ ), the empirical relationship between bacterial numbers and chl a concentration still held true. From our data we agree with Li et al. (1992) that in oligotrophic oceans bacterial biomass may sometimes dominate phytoplankton biomass, but not always.

In general, bacterial biomass in oceanic environments is controlled by phytoplankton production, as stated by Ducklow (1992). In a similar way, it is reasonable to suggest from our data that the characteristics and the composition of bacterial assemblages were also influenced by phytoplankton. In fact, Type I bacteria were most adapted to survive in impoverished environments, which is in agreement with Li (1995) from the oligotrophic Mediterranean Sea. Conversely, Type III bacteria dominated at stations closest to the Sarno River, probably because their growth was being stimulated by riverine inputs, or other factors associated with riverine inputs. Unfortunately, no other data are available on planktonic bacteria of the Gulf of Naples, and very little is known generally about coastal planktonic bacteria. Present knowledge is limited to culturable bacteria, so that we do not know the taxonomic position of the in situ bacterial assemblage. In addition, our group partitioning was based on apparent DNA content, but we cannot be sure whether the differences observed reflected different groups of bacteria or differential stain penetration, due to factors such as physiological status of the population (Li et al. 1995 and references therein). On the other hand, different DNA contents may reflect the observed diversity in marine bacterioplankton (Fuhrman et al. 1994). Several authors have now observed similar populations in different environments by flow cytometry using different dyes (Li et al. 1995, Marie et al. 1997). If these different DNA contents are shown to represent distinct genetic populations, then flow cytometry represents a valuable tool for estimating bacterial numbers, and population distributions could be used as a marker of water mass trophic conditions.
The high values of cell fluorescence allowed us to detect prochlorophytes up to the surface. This could be due to a photoacclimation response to the reduced average light intensity to which cells are exposed in winter because of the deeper mixed layer, as observed in the Pacific Ocean by Campbell \& Vaulot (1993)

The increase in mean fluorescence per cell of cyanobacteria and prochlorophytes with depth reflected increased chlorophyll per cell at decreased light intensities, as has been found by other authors (references in Bautista \& Jimenez-Gomez 1996). This increase was much higher for prochlorophytes (up to 10 times) than for cyanobacteria (up to 3 times), reflecting different physiological responses to light of these 2 prokaryotes (Partensky et al. 1993, Moore et al. 1995). As a matter of fact, prochlorophytes are very abundant and fastgrowing in the deep euphotic zone of different oceanic regions (Veldhuis \& Kraay 1993).

Changes in prochlorophytes, red fluorescence with depth could also be due to shifts among different species as well as physiological shifts within a single species (Campbell \& Vaulot 1993, Moore et al. 1995). We also observed co-occurring populations of prochlorophytes in the MAW. Although this has been found in other oceans (references in Moore et al. 1998), this is the first report for the Mediterranean Sea.

In order to relate phytoplankton data to hydrological and chemical variables, and to infer specific phytoplankton niches, PCA was performed on data combined from the 3 transects. All data have been plotted and each data point represented 1 single sampling depth. The scores of principal Components 1 and 2 for each station have been plotted against each other and 1 general grouping has been drawn to help illustrate patterns. Samples from $70 \mathrm{~m}$ (MAW) all group together (Fig. 9), confirming the peculiarity of this water mass with respect to the others, due to its lower density, and specific phytoplankton pattern (relatively richer in pelagophytes and chlorophytes). These 2 algal groups found suitable conditions for growth in the MAW. The pelagophytes probably exploited the relatively high nutrient concentrations (Letelier et al. 1993), and the chlorophytes may be able to efficiently utilize the blue/violet wavelengths available at low irradiances due to their pigment spectra (Glover et al. 1986). The peculiarity of the MAW, reflected in its phytoplankton composition, such as the low proportion of cryptophytes and unusual $F p$ value, was probably due to its separation from the overlying water, and to its long-term existence.

The co-occurrence of 2 populations of prochlorophytes was typical of the MAW. Among the factors that determine different distributions of different populations of these algae, light appears to be the main one, 


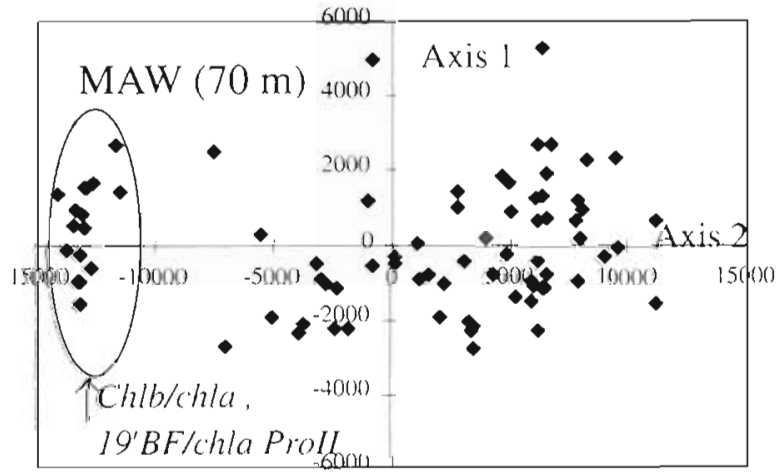

Fig. 9. Cross plot of principal component scores derived from all data collected during this study. Symbols $(\downarrow)$ represent samples. First 2 axes take into account $96 \%$ of variance. All samples from $70 \mathrm{~m}$ (MAW) group together along the $y$-axis. $C h l b / c h l a=$ ratio of chl $b$ (marker of chlorophytes) to chl $a$ $19^{\prime} \mathrm{BF} / \mathrm{chla}=$ ratio of $19^{\prime}$ butanoyloxyfucoxanthin (marker of pelagophytes) to chl a Pro II = second population of prochlorophytes

as elegantly shown by Moore et al. (1998), who compared 2 strains isolated from the same depth and with a flow cytometric signature very similar to ours. Preliminary data from a coastal station of the Gulf of Naples sampled weekly for 1 yr indicate that the cooccurrence of 2 populations is linked to salinity (R. Casotti unpubl. data). As a matter of fact, the 2 populations always co-occurr at salinity values of 37.9 psu which falls within the range of salinity indicated for the MAW (Povero et al. 1990). As a result, the presence of the 2 populations could be due to passive transport inside the MAW of 1 type adapted to low light intensities, and then mixed with the 'local' population (highlight adapted) at its border. If salinity is confirmed as a necessary requirement for the co-occurrence of the 2 populations, this would represent a biological marker of a water mass, in our case the MAW. Of course, further physiological and ecological investigations are needed to explain the exact conditions regulating the co-occurrence of these 2 types of algae, and to assess whether they are both growing.

The eddy occupied the surface layer lying above the MAW. By comparing temperature (higher) and nutrient (lower) data with the surrounding water we assumed that this structure originated from offshore waters. Low phytoplankton biomass and Fp ratio also corroborated this interpretation. From a thermic satellite image (AVHRR) of November 10, it was possible to calculate the internal deformation Rossby radius of this eddy, which was ca $8 \mathrm{~km}$, lying within the range of eddies in the Mediterranean Sea (Robinson et al. 1987). The mechanism of formation of the eddy was probably determined by the general Tyrrhenian circulation pattern. From the border of the flow, eddies can detach and enter the Gulf, where they stay for an indefinite period of time. No data have been published on such eddies in the Gulf of Naples so we have no information on their average lifespan or mechanism of formation. Neither can we compare biological information. At its borders the eddy generates a downwelling, as indicated by an accumulation of biomass rich in diatoxanthin inside the front (Fig. 3c,d). We suggest that the eddy was generated by an anticyclonic circulation of the offshore water mass. Considering its anticyclonic direction, the general oligotrophy of its waters and also the relatively higher chlorophyllide a concentrations inside the eddy (not shown), which indicate senescence of brown algae, we propose the hypothesis that this was an unproductive eddy which was formed some days before our sampling. Unfortunately, cloud coverage in previous or following days did not allow us to confirm our hypothesis by satellite images.

Most studies focus on the effects of large-scale permanent or semi-permanent eddies (for the Mediterranean Sea: Zohary \& Robarts 1992, Yacobi et al. 1995), but little is known about the effects of small, shortlived eddies in semi-enclosed coastal areas, such as the Gulf of Naples. The role of such eddies may represent an important mechanism for diluting terrestrial inputs of nutrients which are brought into the coastal area (as is the case of our eddy), or else, they could limit the extension of the coastal zone, concentrating the nutrients in a more restricted area, causing local eutrophication. Such an effect for pollutants has been observed in the German Bight (Dippner 1993). Coastal eddies strongly influence organism distribution and represent important mechanisms for the entrapment or dispersal of larvae and adults (Lobel \& Robinson 1986, Dippner 1993). Larval fish transport mechanisms can induce fluctuations in recruitment and relative implications for fisheries and therefore the economy of certain areas.

\section{CONCLUSIONS}

Coastal areas are spatially and temporally variable. We have shown that this can be increased by external water masses occupying the lower layers of the water column (like the MAW), or by rotating structures such as eddies. As it is reasonable to think that such phenomena occur several times during an annual cycle, they may be very important in enhancing or depressing primary production (Falkowski et al. 1991), and for providing exchanges with the Tyrrhenian Sea. Our approach represents an attempt to monitor this variability at the mesoscale, coupling HPLC pigment analysis and flow cytometry, in order to relate bulk measurement of pigments to intrinsic parameters on a single-cell basis. 
Acknowledgements. We are grateful to Erik Zettler and Glen Tarran for their competent, efficient and friendly revision of this manuscript. We also wish to thank Fabio Conversano for his continuous help. Marina Montresor and Federico Corato for sharing their data, and the crew of the RV 'Vettoria' for friendly assistance during the sampling. Two anonymous reviewers have been very helpful for their constructive comments on an earlier version of this manuscript. This work has been supported in part by the MAST contract MAS2-CT-945021 to C.B

\section{LITERATURE CITED}

Andersen V, Nival P (1989) Modelling of phytoplankton population dynamics in an enclosed water column. J Mar Biol Assoc UK 69:625-646

Bautista B, Jiménez-Gòmez F (1996) Ultraphytoplankton photoacclimation through flow cytometry and pigment analysis of mediterranean coastal waters. Sci Mar 60(Suppl I): $233-241$

Bird DF, Kalff J (1984) Empirical relationships between bacterial abundance and chlorophyll concentration in fresh and marine waters. Can J Fish Aquat Sci 41:1015-1023

Brunet C, Brylinski JM, Lemoine Y (1993) In situ variations of the xanthophylls diatoxanthin and diadinoxanthin: photoadaptation and relationships with an hydrodynamical system in the eastern English Channel. Mar Ecol Prog Ser 102:69-77

Brunet C, Brylinski JM, Bodineau G, Bentley D, Hilde D (1996) Phytoplankton dynamics during the spring bloom. in the South-Eastern English Channel. Estuar Coast Shelf Sci 43(4):469-484

Buck KR, Chavez FP, Campbell L (1996) Basin-wide distributions of living carbon components and the inverted trophic pyramid of the central gyre of the North Atlantic Ocean, summer 1993. Aquat Microb Ecol 10:283-298

Bustillos-Guzmán J, Claustre H, Marty JC (1995) Specific phytoplankton signatures and their relationships to hydrographic conditions in the coastal northwestern Mediterranean Sea. Mar Ecol Prog Ser 124:247-258

Campbell L, Vaulot D (1993) Photosynthetic picoplankton community structure in the subtropical North Pacific Ocean near Hawaii (station ALOHA). Deep-Sea Res I 40(1.0):2043-2060

Campbell L, Nolla HA, Vaulot D (1994) The importance of Prochlorophytes to community structure in the central North Pacific Ocean. Limnol Oceanogr 39:954-961

Chisholm SW, Olson RJ, Zettler ER, Goericke R, Waterbury JB, Welschmeyer NA (1988) A novel free-living prochlorophytes abundant in the oceanic euphotic zone. Nature $334: 340-343$

Cho BC, Azam F (1990) Biogeochemical significance of bacteria biomass in the ocean's euphotic zone. Mar Ecol Prog Ser 63:253-259

Claustre $H$ (1994) The trophic status of various oceanic provinces as revealed by phytoplankton pigment signatures. Limnol Oceanogr 39:1207-1211

Claustre H, Kerherve JC, Marty JC. Prieur L (1994) Phytoplankton photoadaptation related to some frontal physical processes. J Mar Syst 5:251-265

De Maio A, Moretti M, Sansone E, Spezie GC, Vultaggio M (1978/79) Dinamica delle acque del Golfo di Napoli (Aprile, Settembre, Ottobre 1977) Diffusione delle acque dolci che pervengono dal Golfo. Ann 1st Nav Napoli $47-48: 201-213$

Dippner JW (1993) Larvae survival due to eddy activity and related phenomena in the German Bight. J Mar Syst 4 303-313

Ducklow HW (1992) Factors regulating bottom-up control of bacteria biomass in open ocean plankton communities. Ergeb Limnol 37:207-217

Eppley RW, Peterson BJ (1979) Particulate organic matter flux and planktonic new production in the deep ocean. Nature 282:677-680

Falkowski PG, Ziemann D, Kolber Z, Bienfang P (1991) Role of eddy pumping in enhancing primary production in the ocean. Nature 352:55-58

Fedorov KN (1972) Temperature inversions in the Red and Mediterranean Sea. Oceanology 12(6):795-803

Fuhrman JA, Sleeter TD, Carlson CA, Proctor LM (1989) Dominance of bacterial biomass in the Sargasso Sea and its ecological. implications. Mar Ecol Prog Ser 57:207-217

Fuhrman JA, Lee SH, Masuchi Y, Davis AA, Wilcox RM (1994) Characterization of marine prokaryotic communities via DNA and RNA. Microb Ecol 28:133-145

Glover HE, Keller MD, Guillard RRL (1986) Light quality and oceanic ultraphytoplankters. Nature 319:142-143

Kana TM, Gilbert PM (1987) Effects of irradiance up to $2000 \mu \mathrm{E} \mathrm{m}^{2} \mathrm{~s}^{-1}$ on marine Synechococcus WH7803. II. Photosynthetic responses and mechanisms. Deep-Sea Res $34: 497-516$

Krivosheya VG (1983) Waree circulation and structure in the Tyrrhenian Sea Oceanology 23(1):166-171

Letelier RM, Bidigare RR, Hebel DV, Ondrusek M, Winn CD, Karl DM (1993) Temporal variability of phytoplankton community structure based on pigment analysis. Limnol Oceanogr 38:1420-1437

Li WKW (1995) Composition of ultraphytoplankton in the central North Atlantic. Mar Ecol Prog Ser 122:1-8

Li WKW (1997) Cytometric diversity in marine ultraphytoplankton. Limnol Oceanogr 42(5):874-880

Li WKW, Wood AM (1988) Vertical distribution of North Atlantic ultraphytoplankton: analysis by flow cytometry and epifluorescence microscopy. Deep-Sea Res 35(9): $1615-1638$

Li WKW, Dickie PM, Irwin BD, Wood AM (1992) Biomass of bacteria, cyanobacteria, prochlorophytes and photosynthetic eukaryotes in the Sargasso Sea. Deep-Sea Res 39(3/4):501-519

Li WKW, Dickie PM, Harrison WG, Irwin BD (1993) Biomass and production of bacteria and phytoplankton during the spring bloom in the western North Atlantic Ocean. DeepSea Res 40:307-327

Li WKW, Jellet JF, Dickie PM (1995) DNA distributions in planktonic bacteria stained with TOTO or TO-PRO. Limnol Oceanogr 40(8):1485-1495

Lobel PS, Robinson AR (1986) Transport and entrapment of fish larvae by ocean mesoscale eddies and currents in Hawaiian waters. Deep-Sea Res 33(4):483-500

Marie D, Partensky F, Jacquet S, Vaulot D (1997) Enumeration and cell cycle analysis of natural populations of marine picoplankton by flow cytometry using the nucleic acid stain SYBR Green I. Appl Environ Microbiol 63: 186-193

Modigh M, Saggiomo V, Ribera d'Alcalá M (1996) Conservative features of picoplankton in a Mediterranean eutrophic area, the Bay of Naples. J Plankton Res 18(1): $87-95$

Moore LR, Goericke R, Chisholm SW (1995) Comparative physiology of Synechococcus and Prochlorococcus: influence of light and temperature on growth, pigments, fluorescence and absorptive properties. Mar Ecol Prog Ser. $116: 259-275$ 
Moore LR, Rocap G, Chisholm SW (1998) Physiology and molecular phylogeny of coexisting Prochlorococcus ecotypes. Nature 393:464-467

Moretti M, Sansone E, Spezie GC, De Maio A (1976-77) Alcuni aspetti del movimento delle acque del Golfo di Napoli. Ann 1st Nav Napoli XLV-XLVI:207-217

Murdoch RC (1989) The effects of a headland eddy on surface macro-zooplankton assemblages North of Otago Peninsula, New Zealand. Estuar Coast Shelf Sci 29:361-383

Olson RJ, Zettler ER, DuRand MD (1993) Phytoplankton analysis using flow cytometry. In: Kemp PF, Sherr BF, Sherr EB, Cole JJ (eds) Handbook of methods in aquatic microbial ecology. Lewis Publishers, Chelsea, MI, p $175-186$

Partensky F, Hoepffner N, Li WKW, Ulloa O, Vaulot D (1993) Photoacclimation of Prochlorococcus sp. (Prochlorophyta) strains isolated from the North Atlantic and the Mediterranean Sea. Plant Physiol 101:285-296

Peeken I (1997) Photosynthetic pigment fingerprints as indicators of phytoplankton biomass and development in different water masses of the southern ocean during austral spring. Deep-Sea Res 44:261-282

Pingree RD, Mardell GT, Maddock L (1985) Tidal mixing in the Channel Isles region derived from the results of remote sensing and measurements at sea. Estuar Coast Shelf Sci 20:1-18

Povero P. Hopkins TS, Fabiano M (1990) Oxygen and nutrient observations in the Southern Tyrrhenian Sea. Oceanol Acta 13(3):229-305

Robarts RD, Zohary T, Waiser MJ, Yacobi YZ (1996) Bacterial abundance, biomass and production in relation to phytoplankton biomass in the Levantine Basin of the southeastern Mediterranean Sea. Mar Ecol Prog Ser 137: 273-281

Robinson AR, Hecht A, Pinardi N, Bishop J, Leslie WG, Rosentroub Z, Mariano A.J, Brenner S (1987) Small synoptic/mesoscale eddies and energetic variability of the eastern levantine basin. Nature 327:131-134

Scotto di Carlo B, Tomas CR, lanora A, Marino D, Mazzocchi MG, Modigh M, Montresor M, Petrillo L, Ribera d'Alcalà M. Saggiomo V, Zingone A (1985) Uno studio integrato dell'ecosistema pelagico costiero del Golfo di Napoli. Nova Thalassia 7(Suppl 3):99-128

Stewart AJ, Wetzel RG (1986) Cryptophytes and other

Editorial responsibility: Otto Kinne (Editor),

Oldendorf/Luhe, Germany microflagellates as couplers in planktonic community dynamics. Arch Hydrobiol 106:1-19

Vaulot D, Partensky F (1989) Winter distribution of marine cyanobacteria (Synechococcus spp.) in the North-Western mediterranean Sea. In: Martin JM, Barth $\mathrm{H}$ (eds) Water pollution research reports 13: EROS 2000 (European River Ocean System) Project Workshop. CEC, Brussels, p $136-149$

Vaulot D, Courties C, Partensky F (1989) A simple method to preserve oceanic phytoplankton for flow cytometric analyses. Cytometry 10:629-635

Vaulot D, Partensky F, Neveux J, Mantoura RFC, Llewellyn C (1990) Winter presence of prochlorophytes in surface waters of the northwestern Mediterranean Sea. Limnol Oceanogr 35:1.156-1164

Veldhuis MJW, Kraay GW (1991) Vertical distribution and pigment composition of a picoplanktonic prochlorophyte in the subtropical North Atlantic: a combined study of HPLC-analysis of pigments and flow cytometry. Mar Ecol Prog Ser 68:121-127

Veldhuis MJW, Krady GW (1993) Cell abundance and fluorescence of picoplankton in relation to growth irradiance and nitrogen availability in the Red Sea. Neth J Sea Res 31:135-145

Yacobi YZ, Zohary T, Kress N, Hecht A, Robarts RD, Waiser M. Wood AM, Li WKW (1995) Chlorophyll distribution throughout the southeastern Mediterranean in relation to the physical structure of the water mass. J Mar Syst 6: $179-190$

Yoder JA, Verity PG, Bishop SS, Hoge FE (1993) Phytoplankton chlorophyll a, primary production and nutrient distributions across a coastal frontal zone off Georgia, USA. Cont Shelf Res 13:131-141

Zingone A, Casotti R, Ribera d'Alcalá M, Scardi M, Marino D (1995) 'St. Martin's Summer': the case of an autumn phytoplankton bloom in the Gulf of Naples (Mediterranean Sea) J Plankton Res 17(3):575-593

Zohary T, Robarts RD (1992) Bacterial numbers, bacterial production, and heterotrophic nanoplankton abundance in a warm core eddy in the Eastern Mediterranean. Mar Ecol Prog Ser 84:133-137

Zweifel UL, Hagström $\AA$ (1995) Total counts of marine bacteria include a large fraction of non-nucleoid-containing bacteria (ghosts). A.ppl Environ Microbiol 61:2180-2185

Submitted: April 13, 1999; Accepted: September 21, 1999

Proofs received from author(s): March 7, 2000 